\title{
HUBUNGAN ASUPAN ZAT BESI DENGAN STATUS ANEMIA REMAJA PUTRI DI KOTA BOGOR
}

\author{
Tyas Permatasari $^{1}$, Dodik Briawan ${ }^{2}$, Siti Madanijah $^{3}$ \\ Prodi Gizi, Fakultas Teknik ${ }^{2,3}$ \\ Universitas Negeri Medan ${ }^{1}$, Institut Pertanian Bogor ${ }^{2,3}$ \\ tyaspermata@unimed.ac.id ${ }^{1}$, dbriawan@yahoo.com²
}

\begin{abstract}
Iron deficiency anemia (IDA) is a worldwide problem with prevalence in developing countries and especially in adolescent girl. Few studies determined the association between estimated iron intakes with IDA. This study aims to analyze the relationship dietary of iron with iron deficiency anemia.

The association between dietary iron intake and iron status was studied in 172 adolescent girls aged 14-16 years between September 2016 until Januari 2017. A cross-sectional design was applied in this study. Blood was collected through fingerthick and analyzed with cyanmethemoglobin method. Dietary iron were taken using a Semi Quantitative Food Frequency Questionaire (FFQ). Data were analzed using Chi-Square. The overall prevalence of anemia was 20.9\% (36/172).. Consumption of dietary iron such as chicken liver, eggs, fish and meat are classified as rarely consumed by adolescent girl. Almost all students of nutrient sufficiency to iron is still classified very low (97\%) Besides also consumption of vegetable and fruit source of vitamin $C$ as enhancer also still classified very low (33.7\%). Consumption of iron, vitamin $C$, protein and nutritional status are not associated with anemia status Moderete prevalence of anemia among adolescent girl in Bogor. There is no significant relationship between Consumption of dietary iron and anemia status.
\end{abstract}

KeyWord: Adolscent Girl, Dietary Of Iron, Iron Deficiency Anemia

\begin{abstract}
ABSTRAK
Anemia defisiensi besi merupakan masalah gizi mikro yang terjadi di seluruh dunia. Masalah ini banyak dialami oleh remaja putri dikarenakan pada usia ini remaja. Salah satu penyebabnya yakni dipengaruhi oleh konsumsi makanan sumber besi. Tujuan penelitian ini yakni ingin mengetahui hubungan konsumsi makanan sumber besi terhadap status anemia pada remaja putri di Kota Bogor. Penelitian ini menggunakan desain cross sectional pada 172 siswi SMP dan SMA di Kota Bogor yang dilaksanakan pada bulan September 2016 sampai Januari 2017. Data kadar HB dianalisis menggunakan metode cyanmethemoglobin. Data konsumsi sumber zat besi dan pengetahuan gizi diambil menggunakan Food Frequency Questionaire (FFQ) semi kuantitatif. Pengolahan data dan analisis menggunakan uji Chi-Square. Prevalensi anemia pada remaja putri di Kota Bogor yakni $20.9 \%$ (36/172). Konsumsi makanan sumber zat besi seperti hati ayam, telur, ikan dan daging tergolong masih jarang dikonsumsi oleh remaja putri. Hampir semua siswi kecukupan gizi akan zat besi masih tergolong kurang (97\%). Selain itu juga konsumsi sayur dan buah sumber vitamin C sebagai enhancer juga masih tergolong sangat rendah (33.7\%). Hasil analisis korelasi menyatakan konsumsi zat besi, vitamin C, protein dan status gizi tidak berhubungan dengan status anemia. Status anemia di Kota Bogor termasuk dalam kategori sedang, dan tidak terdapat hubungan anatara asupan besi dengan kejadian anemia.
\end{abstract}

Kata Kunci : Anemia Defisiensi Besi, Konsumsi Sumber Besi, Remaja Putri. 


\section{PENDAHULUAN}

Masalah kesehatan masyarakat yang masih banyak terjadi pada remaja yakni anemia, masalah anemia ini tidak hanya terjadi di negara berkembang tetapi juga di negara maju. Anemia dapat berisiko terjadi pada semua kelompok usia, dan kelompok yang berisiko tinggi untuk menderita anemia adalah anak usia sekolah, remaja, wanita usia subur (WUS), dan ibu hamil. Anemia gizi besi (AGB) merupakan anemia yang paling banyak terjadi pada remaja. Prevalensi terbesar terjadi di Negara Afrika dan Asia Tenggara (WHO, 2015).

Kelompok yang rawan mengalami anemia adalah kelompok remaja putri (1019 tahun). Padahal mereka merupakan generasi masa depan bangsa yang nantinya akan menentukan generasi berikutnya. Pada remaja wanita diperkirakan prevalensi global anemia adalah (29.4\%) (WHO, 2015). Di Indonesia sendiri, diketahui bahwa prevalensi anemia pada remaja usia 15-24 tahun adalah (18.4\%), sehingga juga dapat dkategorikan masalah kesehatan sedang (Kemenkes 2013).

Faktor risiko anemia yang paling utama antara lain adalah rendahnya asupan zat gizi besi, rendahnya penyerapan besi dari pangan tinggi senyawa fitat dan fenolik, serta adanya periode kehidupan manusia dimana kebutuhan besi semakin meningkat (seperti pada masa pertumbuhan dan kehamilan) termasuk dalam periode remaja. Pangan sumber zat besi terutama zat besi heme, yang bioavailabilitasnya tinggi, sangat jarang dikonsumsi oleh masyarakat di negara berkembang, yang kebanyakan memenuhi kebutuhan besi mereka hanya dari produk nabati (Backstrand et al. 2002). Pola konsumsi makan masyarakat Indonesia masih didominasi sayuran sebagai sumber zat besi yang sulit diserap. Sementara itu, daging dan bahan pangan hewani sebagai sumber zat besi yang baik (heme iron) jarang dikonsumsi terutama oleh masyarakat pedesaan (Depkes 1998). Besi heme yang terdapat dalam pangan hewani dapat diserap dua kali lipat daripada besi nonheme. Besi dalam makanan terdapat dalam bentuk besi heme (dalam hemoglobin dan mioglobin makanan hewani) dan besi nonheme (dalam makanan nabati). Sumber besi nonheme yang baik diantaranya adalah kacang-kacangan. Oleh karena itu penelitian ini bertujuan mengkaji hubungan konsumsi sumber besi dengan kejadian anemia pada remaja putri di Kota Bogor.

\section{METODE}

Penelitian dilakukan menggunakan desain cross sectional. Penelitian dilakukan di Kota Bogor, Provinsi Jawa Barat. Pelaksanaan penelitian dilakukan mulai September 2016 hingga Januari 2017. Populasi subjek dalam penelitian ini adalah remaja putri berusia 11-18 dari SMP dan SMA di Kota Bogor yang mengikuti program pemberian tablet tambah darah dari Dinas Kesehatan Kota Bogor. Penelitian ini dilaksanakan pada 2 SMP dan 2 SMA sederajat di Kota Bogor.

Pemilihan subjek berdasarkan kriteria inklusi yakni siswa yang mengikuti penjaringan yang diadakan oleh puskesmas, bersedia mengikuti penelitian hingga selesai serta mendapatkan izin dari orangtua. Kriteria eksklusi subjek yaitu siswa pindah sekolah dan siswa sedang 
menjalani pengobatan pada penyakit infeksi atau penyakit yang kontraindikasi dengan pemberian tablet Fe.

Data yang dikumpulkan dalam penelitian ini meliputi karakteristik individu subjek (umur, status gizi, dan kadar $\mathrm{Hb}$ ), kebiasaan makan, pola konsumsi dan status anemia. Data konsumsi pangan dikumpulkan dengan metode Food Frequency Questionnare (FFQ) semi kuantitatif.

Dalam pengukuran antropometri, pengukuran berat badan menggunakan timbangan digital, sementara pengukuran tinggi badan menggunakan microtoise. Pengambilan darah diambil sebanyak $20 \mu \mathrm{l}$ melalui pembuluh darah kapiler yang diambil oleh tenaga kesehatan yang terlatih dari puskesmas di Kota Bogor. Selanjutnya analisis kadar $\mathrm{Hb}$ dilakukan di laboratorium puskesmas masing-masing dengan metode cyanmethemoglobin menggunakan spektrofotometer.

Data status gizi diperoleh dengan mengolah data antopometri menggunakan WHO AnthroPlus. Untuk mengukur status gizi remaja digunakan indeks masa tubuh berdasarkan umur (IMT/U). Kategori status gizi berdasarkan WHO (2007) yaitu sangat kurus ( $<<-3 S D)$, kurus $(-3 \mathrm{SD} \leq \mathrm{Z} \leq-2 \mathrm{SD})$, normal $(-2 \mathrm{SD}<\mathrm{Z} \leq$ +1 SD), gemuk $(+1 S D<Z \leq+2$ SD) dan obesitas $(\mathrm{Z}>+2 \mathrm{SD})$.

Penentuan pola konsumsi pangan menggunakan Food Frequency Questionnaires (FFQ) semi kuantitatif. Kadar hemoglobin subjek diketahui melalui analisis biokimia di Puskesmas yang membawahi masing-masing sekolah. Kadar hemoglobin dianalisis dengan menggunakan metode cyanmethemoglobin. Status anemia dibedakan menjadi 2 yaitu anemia dan tidak anemia. Penelitian ini telah mendapatkan ethical clearance dari komisi etik Fakultas Kedokteran Universitas Indonesia

No.62/UN2.F1/ETIK/2017

\section{HASIL}

Distribusi Frekuensi Karakteristik Subjek Remaja Putri

Tabel 1. Karakteristik Remaja Putri di Kota Bogor

\begin{tabular}{lll}
\hline Karakteristik & \multicolumn{2}{c}{ Jumlah } \\
\cline { 2 - 3 } & Frekuensi (n) & Persen (\%) \\
\hline Umur (tahun) & & \\
$<15$ tahun & 104 & $60.5 \%$ \\
$\geq 15$ tahun & 68 & $39.5 \%$ \\
\hline Status gizi & & \\
Kurus & 18 & $10.5 \%$ \\
Normal & 122 & $70.9 \%$ \\
Gemuk & 32 & $18.6 \%$ \\
\hline
\end{tabular}

Sumber : Data Primer

Karakteristik remaja putri di Kota Bogor berdasarkan umur dan status gizi ditunjukkan pada (Tabel 1). Status gizi subjek sebagian besar $(70.9 \%)$ termasuk kategori normal. Terdapat subjek dengan status gizi sangat kurus (10.5\%), selain itu juga terdapat subjek tergolong gizi lebih (18.6\%) (Tabel 1).

\section{Distribusi Status Anemia Subjek Remaja Putri}

Tabel 2. Status Anemia Remaja Putri di Kota Bogor

\begin{tabular}{lccc}
\hline $\begin{array}{c}\text { Status } \\
\text { Anemia }\end{array}$ & $\begin{array}{c}\text { Frekuensi } \\
(\mathbf{n})\end{array}$ & $\begin{array}{c}\text { Persen } \\
(\boldsymbol{\%})\end{array}$ & Mean \pm SD \\
\hline Anemia & 36 & 20.9 & $\begin{array}{c}12.77 \pm 1.23 \\
\text { g/dl }\end{array}$ \\
\hline Normal & 136 & 79.1 & \\
\hline Total & 172 & 100 & \\
\hline Sumber : Data Primer & &
\end{tabular}


Prevalensi anemia pada remaja putri di Kota Bogor sebesar 20.9\% dari 172 subjek yakni sekitar 36 remaja mengalami anemia. Sebaran prevalensi anemia dan anemia tingkat ringan $88.8 \%$ (32 subjek) tingkat sedang $11.1 \%$ (4 subjek). Rata-rata kadar $\mathrm{Hb}$ yang diuji menunjukkan rata-rata kadar hemoglobin $12.77 \pm 1.23 \mathrm{~g} / \mathrm{dl}$, dengan konsentrasi hemoglobin subjek berkisar antara $8.10 \mathrm{~g} / \mathrm{dl}$ hingga $16.60 \mathrm{~g} / \mathrm{dl}$ (Tabel 2).

\section{Rata-rata Konsumsi Pangan}

Tabel 3. Rata-rata konsumsi pangan (g/hari)

\begin{tabular}{lc}
\hline \multicolumn{1}{c}{ Bahan makanan } & Mean \pm SD \\
\hline Daging & $6.94 \pm 1.17$ \\
Ayam & $20.69 \pm 1.84$ \\
Hati & $0.87 \pm 2.50$ \\
Ikan & $11.03 \pm 2.15$ \\
Telur & $20.49 \pm 1.38$ \\
Tempe dan Tahu & $46.84 \pm 2.53$ \\
Sayur & $30.95 \pm 1.91$ \\
Buah & $39.65 \pm 30.17$ \\
Teh & $79.89 \pm 1.62$ \\
\hline Sumber : Data Primer
\end{tabular}

Hasil Rata-rata konsumsi pangan per hari subjek disajikan pada (Tabel 3). Dari tabel terlihat rata-rata konsumsi lauk hewani daging sapi adalah $6.94 \pm 1.17$ g/hari, daging ayam $20.69 \pm 1.84 \mathrm{~g} / \mathrm{hari}$, ikan $11.03 \pm 1.78 \mathrm{~g} /$ hari, hati $0.87 \pm 2.50$ dan telur $20.49 \pm 1.38 \mathrm{~g} /$ hari. Lauk hewani yang paling sering dikonsumsi remaja putri di Kota Bogor yaitu telur, sedangkan hati dan daging sapi merupakan lauk hewani yang paling jarang dikonsumsi. Rata-rata konsumsi tahu tempe adalah $46.84 \pm 2.53$ g/hari. Konsumsi sayur dan buah masih tergolong rendah yaitu sayur $30.95 \pm 1.91$ dan buah $39.65 \pm 30.17$. selain itu konsumsi teh sebesar $79.89 \pm 1.62$.

\section{Hubungan Konsumsi Zat Besi dengan Status Anemia}

Hasil tabulasi silang (Tabel 4) menunjukkan bahwa subjek tergolong dalam tingkat kecukupan protein, Fe dan vitamin $\mathrm{C}$ masih tergolong kurang. Pada angka kecukupan protein berturut turut $(79.1 \%)$ dan $(97.1 \%)$ dalam kategori kurang sedangkan dalam kecukupan Vitamin C tergolong cukup (66.3\%). Hasil uji korelasi chi-square menunjukkan hasil tidak terdapat hubungan antara kecukupan asupan protein, zat besi serta vitamin $\mathrm{C}$ terhadap kejadian anemia $(\mathrm{p} \geq 0)$.

Tabel 4. Hubungan Konsumsi Zat Besi dan Status Anemia

\begin{tabular}{|c|c|c|c|c|c|c|c|c|}
\hline \multicolumn{2}{|c|}{ Zat gizi } & \multicolumn{4}{|c|}{ Kejadian anemia } & \multicolumn{2}{|c|}{ Total } & \multirow[t]{2}{*}{$p$} \\
\hline & & \multicolumn{2}{|c|}{ Anemia } & \multicolumn{2}{|c|}{ Normal } & & & \\
\hline & & $\mathbf{n}$ & $\%$ & $\mathbf{n}$ & $\%$ & $\mathbf{n}$ & $\%$ & \\
\hline \multirow[t]{2}{*}{ Protein } & Kurang & 26 & 15.1 & 110 & 64 & 136 & 79.1 & 0.25 \\
\hline & Cukup & 10 & 5.8 & 26 & 15.1 & 36 & 20.9 & \\
\hline \multirow[t]{2}{*}{ Zat Besi } & Kurang & 34 & 19.8 & 133 & 77.3 & 167 & 97.1 & 0.28 \\
\hline & Cukup & 2 & 1.2 & 3 & 1.7 & 5 & 2.9 & \\
\hline \multirow[t]{2}{*}{ Vitamin C } & Kurang & 11 & 6.4 & 47 & 27.3 & 58 & 33.7 & 0.65 \\
\hline & Cukup & 25 & 14.5 & 89 & 51.7 & 114 & 66.3 & \\
\hline
\end{tabular}

Sumber : Data Primer 


\section{PEMBAHASAN}

\section{Karakteristik Subjek}

Sebagian besar subjek berusia kurang dari 15 tahun $(60.5 \%)$ rentang usia ini merupakan batasan usia remaja awal (early adolescence) yaitu antara 12-15 tahun. Subjek merupakan siswi kelas 7 pada SMP dan siswi kelas 10 pada SMA. Dalam penilitian ini umur subjek berkisar antara 12 - 18 tahun. Rentang usia ini merupakan kisaran usia dalam kategori usia remaja awal dan menengah. Bila dibandingkan menurut tingkat sekolah, umur anak SMP termasuk kategori remaja awal dan SMA remaja pertengahan serta remaja akhir) (Brown, 2011). Remaja memiliki pertumbuhan yang cepat (growth spurt) dan merupakan waktu pertumbuhan yang intens setelah masa bayi serta satu-satunya periode dalam hidup individu terjadi peningkatan velositas pertumbuhan (Brown, 2011). Kekurangan zat gizi makro dan mikro dapat mengganggu pertumbuhan dan menghambat pematangan seksual (DiMeglio, 2000). Selain itu juga usia remaja ini merupakan usia dimana seseorang memulai pencarain jati diri sehingga mempengaruhi pembentuka pola konsumsi mereka. Bila remaja putri tidak dibekali pengetahuan gizi yang tepat akan berdampak pada masalah gizi. Salah satunya yaitu anemia.

Status gizi juga memiliki peranan terhadap risiko permasalahan remaja anemia. Subjek dengan status gizi yang baik cenderung memiliki status kesehatan yang baik, produksi hemoglobin juga akan meningkat ketika fungsi tubuh normal sehingga produksi hemoglobin juga akan lebih meningkat saat konsumsi $\mathrm{Fe}$ juga meningkat (Mahan LK, 2019). Remaja yang mempunyai status gizi kurang berkorelasi dengan kejadian anemia. IMT mempunyai korelasi positif dengan konsentrasi hemoglobin yang artinya jika seseorang memiliki IMT kurang maka akan berisiko menderita anemia (Sukarno et al, 2016). Penelitian lain yang dilakukan pada remaja putri di India menunjukkan hasil yang berbeda yakni IMT tidak berkorelasi dengan kejadian kadar hemoglobin (Kaur et al, 2015).

\section{Hubungan Konsumsi Pangan dengan Status Anemia}

Anemia terjadi apabila kepekatan hemoglobin dalam darah di bawah batas normal. Anemia memiliki banyak jenis salah satunya yakni anemia gizi besi yang paling sering dialami oleh remaja putri. Anemia gizi besi ditandai dengan penurunan kadar hemoglobin dan kadar serum besi. Pada penelitian ini, status anemia ditentukan menggunakan indikator hemoglobin. Anak usia 11 sampai 14 tahun dan remaja putri di atas 15 tahun dikatakan anemia jika kadar hemoglobinnya $<12 \mathrm{~g} / \mathrm{dl}$ (Proverawati, 2011). Dari data kadar hemoglobin tersebut dapat ditentukan penggolongan jenis anemia subjek menjadi ringan (10-11.9 g/dl), sedang (7-9.9 g/dl), dan berat (kadar $\mathrm{Hb}<7 \mathrm{~g} / \mathrm{dl}$ ) .

Dalam penelitian ini adanya subjek yang berada pada kondisi anemia sedang dapat berdampak pada status imunitas dan fungsi kognitifnya (Ruel, 2001). Menurut Soekirman (2000), anemia pada kelompok remaja dapat menimbulkan berbagai dampak antara lain menurunkan daya tahan tubuh sehingga mudah terkena penyakit dan menurunkan aktivitas yang berkaitan dengan kemampuan kerja fisik dan prestasi belajar. Di Indonesia dampak anemia pada remaja putri selain lamanya studi juga berpengaruh terhadap kemampuan akademik. UNDP (2015) menyatakan 
bahwa skor membaca, nilai matematika dan skor IPA sebagai indikator capaian pendidikan, Indonesia masih tergolong rendah jika dibandingkan dengan negara ASEAN lainnya seperti Singapura, Malaysia, Thailand dan Vietnam. Penyebab utama terjadinya anemia pada remaja putri yakni rendahnya konsumsi pangan sumber besi serta adanya penyakit infeksi (kecacingan dan malaria). Selain itu terdapat faktor lain yang tidak langsung memengaruhi kejadian anemia yakni sosial ekonomi keluarga, karakteristik responden dan status menstruasi.

Faktor yang paling dominan dari permsalahan anemia pada remaja yakni terkait pola pangan sumber besi. Total konsumsi lauk hewani pada remaja putri di Kota Bogor masih tergolong rendah. Menurut anjuran pedoman gizi seimbang (PGS) mengenai ukuran porsi konsumsi anak remaja perempuan usia 16-18 tahun untuk lauk hewani adalah 3 p (150 g), jika dibandingkan hasil penelitian ini rata-rata konsumsi lauk hewani baru mencapai $39 \%$. Hasil penelitian ini sejalan dengan penelitian pada siswi di Tasikmalaya yakni asupan besi hanya sekitar 4.2-5.2 mg/hari (Susanti 2016). Demikian pula pada penelitian di Makassar hampir seluruh subjek tergolong kurang dari AKG yakni sebanyak 94\% tidak cukup asupan zat besi (Rahayu 2011).

Jumlah lauk nabati yang paling sering dikonsumsi subjek remaja yakni tahu dan tempe tidak besar karena tidak lebih dari satu potong tempe ukuran sedang. Jika dibandingkan dengan anjuran Pedoman Gizi Seimbang konsumsi lauk nabati sebesar $3 \mathrm{p}(150 \mathrm{~g})$, maka rata-rata konsumsi lauk nabati tersebut baru mencapai $31.2 \%$. Konsumsi sayur dan buah masih tergolong rendah yaitu sayur $30.95 \pm 1.91$ dan buah $39.65 \pm 30.17$, jumlah ini jika dibandingkan PGS masih tegolong rendah karena yang dianjurkan sekitar 1-3 porsi sehari dengan takaran 1 porsi yakni 100gr bahan kering. Sedangkan minuman berbahan teh dikonsumsi dengan jumlah cukup yakni rata-rata $79.89 \pm 1.62$ (Kemenkes 2014).

Pada penelitian ini presentase AKG dari semua zat gizi masih tergolong dalam kategori $<70 \%$ AKG. Hal ini sejalan dengan penelitian Briawan (2008) bahwa \% AKG protein maupun besi serta vitamin $C$ tidak berpengaruh terhadap perubahan kadar hemoglobin dan perbaikan status anemia. Selain itu juga tidak terdapatnya hubungan asupan besi dengan status anemia juga sejalan dengan penelitian pada remaja di Kota Surabaya (Lestari et al 2017).

\section{KESIMPULAN}

Status anemia di Kota Bogor termasuk dalam kategori sedang. Tidak terdapatnya hubungan yang signifikan antara asupan besi, protein serta vitamin $\mathrm{C}$ terhadap status anemia remaja putri di Kota Bogor. Penelitian ini masih terdapat kekurangan dan perlu dilakukan penelitian lanjutan terkait pola konsumsi asupan besi, makanan sumber enhancer serta inhibitor dalam pengaruhnya terhadap status anemia remaja.

\section{DAFTAR PUSTAKA}

Backstrand JR, Allen LH, Black AK, deMata M, Pelto GH. (2002). Diet and iron status of nonpregnant women in rural Central Mexico. The 
Journal of Nutrition, 76(1),pp. 156-64

Briawan, D. (2008). Efikasi suplementasi besi-multivitamin terhadap perbaikan status besi remaja wanita. Disertasi. Bogor: Fakultas Ekologi Manusia Institut Pertanian Bogor.

Brown, JE. (2011). Nutrition Through the Life Cycle. Wadsworth: Cengage Learning.

Di Meglio, G. (2000). Nutrition in Adolescence. Journal of the American Academy of Pediatrics

Departemen Kesehatan RI (1998). Pedoman Penanggulangan Anemia Gizi untuk Remaja Putri dan Wanita Usia Subur. Jakarta: Direktorat Jenderal Pembinaan Kesehatan Masyarakat.

Indriasari, R. (2011). An examination of the eating behaviour of adolescent girls in Indonesia: formative research for prevention of iron deficiency. Disertation. Quennsland: School of Population Health, The University of Queensland

Lestari, IP., Lipoeto, NI., Amurdi. (2017). Hubungan Konsumsi Zat Besi dengan Kejadian Anemia pada Murid SMP Negeri 27 Padang. Jurnal Kesehatan Andalas, 6(3): pp. 507-511.

Kaur, M., Singh A., dan Bassi, R. (2015). Nutritional Status and Anaemia in Medical Students of Sgrdimsar, Amritsar. National Journal of Physiology, Pharmacy \& Pharmacology, 5(1):pp.35-49.

Kementrian Kesehatan. (2013). Hasil Riset Kesehatan Dasar 2013. Jakarta:
Badan Penelitian dan

Pengembangan Kesehatan.

Kementrian Kesehatan. (2014). Peraturan Menteri Kesehatan Republik Indonesia Nomor 88 Tahun 2014. Jakarta: Kementerian Kesehatan RI.

Mahan, LK., Raymond, JL. (2019). Krause's Food and The Nutrition Care Process. Missouri: Elsevier.

Proverawati. (2011). Buku Anemia dan Anemia Kehamilan . Yogyakarta: Nuha Medika.

Ruel, MT. (2001). Can Food-Based Strategies Help Reduce Vitamin A and Iron Deficiencies? A Review of Recent Evidence. Washington DC: International Food Policy Research Institute

Sukarno, KJ., Marunduh, SR., dan Pangemanan DHC. (2016). Hubungan Indeks Massa Tubuh Dengan Kadar Hemoglobin Pada Remaja Di Kecamatan Bolangitang Barat Kabupaten Bolaang Mongondow Utara. Jurnal Kedokteran Klinik, 1(1):pp. 1-7.

Susanti, Y., Briawan, D., Martianto, D. (2016). Suplementasi besi mingguan meningkatkan hemoglobin sama efektif dengan kombinasi mingguan dan harian pada remaja putri. J Gizi Pangan, 11(1):pp. 27-34.

United Nation Development Program. (2015). Human Development Report 2015, work for human development [report]. USA: United Nation Development Program.

World Health Organization. (2015). The Global Prevalence of Anaemia in 2011. Geneva: World Health Organization. 